\title{
ADHD: strategies to unravel its genetic architecture
}

\author{
J. K. Buitelaar \\ Department of Psychiatry (333), Radboud University Nijmegen Medical Center, \\ Nijmegen, The Netherlands
}

Summary. Attention deficit/hyperactivity disorder (ADHD) is a common and impairing neuropsychiatric disorder with onset at preschool age and strong persistence over time. Its validity as a psychiatric disorder has been established according to Robins and Guze criteria. Genetic factors predominate in the etiology of ADHD. This paper summarizes the current status of genetic research into ADHD, and describes eight factors that complicate research into genetically complex disorders as ADHD. These factors are that multiple genes of small main effects are involved rather than main genes, the relevant phenotype is unknown, presence of clinical heterogeneity, presence of genetic heterogeneity, gene-environment correlation, gene-environment interaction, importance of endophenotypes, and importance of developmental factors. The further unraveling of the genetic architecture of ADHD will depend to a large extent on how well these complicating factors are handled or even used.

\section{Introduction}

Attention deficit/hyperactivity disorder (ADHD) is a common and impairing neuropsychiatric disorder with onset at preschool age. It is thought to affect $3-5 \%$ of all schoolage children and is characterized by age-inappropriate symptoms of hyperactivity, inattentiveness and impulsivity (American Psychiatric Association, 1994; Buitelaar, 2002). This pattern can be viewed as the extreme of a complex trait that is continuously distributed in the general population and shows a strong overlap with aggressive behavior. The Fourth Edition of the Diagnostic and Statistical Manual (DSM-IV) recognizes three subtypes of ADHD, the predominantly inattentive subtype, the predominantly hyperactive-impulsive subtype and the combined subtype (American Psychiatric Association, 1994). Eighty percent of the children that are diagnosed with ADHD display symptoms in all three domains of inattentiveness, hyperactivity and impulsivity, though at the level of the general population, the inattentive subtype of ADHD is most prevalent (Buitelaar, 2002). There is a much higher incidence rate in boys, who are 1.5-5.8 times more likely than girls to be diagnosed with ADHD (Buitelaar, 2002). The disorder often has a chronic course with about $70 \%$ of affected children having threshold ADHD symptoms and associated impairment in 
adolescence and 30-50\% of affected children displaying ADHD symptoms into adulthood (Weiss et al., 1993; Barkley et al., 1990). The presence of comorbid disorders is the rule rather than the exception. Common comorbidities in children and adolescents include oppositional defiant disorder and conduct disorder, anxiety disorders, mood disorders (Biederman et al., 1991), tic disorders, motor coordination disorder (Robinson et al., 1993), learning disabilities (SemrudClikeman et al., 1992) and problems in reciprocal social interaction and communication that overlap with those described in autism spectrum disorders (Luteijn et al., 2000a, b). In adolescence and adulthood, comorbid risk taking behaviors and substance abuse disorders are rising in prevalence (Wilens, 2004) as well as antisocial personality disorder (Mannuzza et al., 1989) and borderline personality disorder (Fossati et al., 2002). Numerous problems are further associated over development with ADHD, such as poor academic performance, school drop out, social isolation, and lower occupational success (Weiss et al., 1993; Barkley et al., 1990).

ADHD has been firmly established as a psychiatric disorder that meets the criteria for the validation of psychiatric diagnoses as outlined by Robins and Guze (1970) (Faraone, 2005a). In spite of this, the disorder's validity has been challenged and criticized by popular media, journalists and politicians (Buitelaar and Rothenberger, 2004). ADHD has been stated to be a result of inadequate parenting and teaching in an overstressed society which places to high demands on children's self-control and self-organizational skills. Normal developmental variation and particularly boyish energy and adventurousness have been medicalized. Worries have been further expressed about potential overdiagnosis and overtreatment of ADHD, and particularly on the dangers of the treatment with psychostimulants. Unfortunately, this has led to increase barriers for referral and block access to adequate diagnosis and treatment for children with ADHD and their parents (Buitelaar and Rothenberger, 2004).

The aim of this communication is to summarize the current status of genetic research into ADHD and to describe strategies to further unravel ADHD's genetic architecture.

\section{Behavior-genetic studies}

Twin, family, adoption and molecular genetic studies show that genes play a very substantial role in the etiology of ADHD. Family-genetic studies indicate that ADHD aggregates in families, with a 5-8 fold increased risk in first-degree relatives and a 2-fold increased risk in second-degree relatives (Faraone et al., 1994). Twin studies found evidence for a narrow additive heritability of 0.75 to 0.91 which was robust across familial relationships and across definitions of ADHD as the end of a continuum or as a disorder with various symptom cutoffs (Levy et al., 1997; Sherman et al., 1997). For further review of twin studies, see Faraone et al. (2001) and Thapar et al. (1999). Given the modest relative risk ratios in siblings and the fall-off in risk from first to second-degree relatives, the high heritability of ADHD is likely to be due to multiple genes of small effect size (called quantitative trait loci, QTLs, or susceptibility genes) rather than a few genes of major effect. The latter result of the twin studies further indicates 
that a QTL approach to the study of the genetics of ADHD is valid and that genes associated with a complex trait measure of ADHD very likely will also show to be relevant for ADHD defined as a categorical psychiatric disorder, and vice versa. The fact that heritability is less than 1.0 shows further that features of the environment are also involved in the etiology of the disorder.

Adoption studies of ADHD also implicate genes in its etiology. The adoptive relatives of ADHD children are less likely to have ADHD or associated disorders than are the biological relatives of ADHD children (Morrison et al., 1973; Cantwell, 1975). Biological relatives of ADHD children also do more poorly on standardized measures of attention than do adoptive relatives of ADHD children (Alberts-Corush et al., 1986).

\section{Genome scans}

To date, there have been performed three independent genome scans of ADHD. Table 1 summarizes their main results. A first genomewide scan for loci involved in ADHD in 126 affected sib pairs pointed to a number of chromosomal sites that may contain risk factors of moderate effect (Fisher et al., 2002). None of these exceeded genomewide significance thresholds, with LOD scores $>1.5$ (but $<1.66$ ) on $5 \mathrm{p} 12,10 \mathrm{q} 26,12 \mathrm{q} 23$ and $16 \mathrm{p} 13$. The regions containing 29 out of 36 candidate genes, including DRD4 and DAT1, could be excluded for a $\lambda$ of 2 . An extension study in a larger sample of 227 ASPs that focused on chromosome 16q13 was able to establish linkage (LOD score 4.2) (Smalley et al., 2002). A further follow-up investigation extended the original sample of 126

Table 1. Summary of regions implicated in genome scans of ADHD and overlap with regions implicated in other disorders

\begin{tabular}{lllll}
\hline Study & Region & LOD & $\begin{array}{l}\text { Implicated in } \\
\text { autism }^{4}\end{array}$ & $\begin{array}{l}\text { Implicated in } \\
\text { dyslexia }^{5}\end{array}$ \\
\hline UCLA $^{1}$ & $5 \mathrm{p} 13$ & 2.6 & $\mathrm{X}$ & \\
UCLA $^{1}$ & $6 \mathrm{q} 12$ & 3.3 & & \\
UCLA $^{1}$ & $16 \mathrm{p} 13$ & 3.7 & $\mathrm{X}$ & $\mathrm{X}$ \\
UCLA $^{1}$ & $17 \mathrm{p} 11^{\#}$ & 3.6 & $\mathrm{X}$ & \\
Netherlands $^{2}$ & $15 \mathrm{q} 15$ & 3.5 & $\mathrm{X}$ & \\
Netherlands $^{2}$ & $7 \mathrm{p} 13$ & 3.0 & & \\
Netherlands $^{2}$ & $9 \mathrm{q} 33$ & 2.1 & & \\
Columbia $^{3}$ & $17 \mathrm{p} 11^{\#}$ & 2.8 & $\mathrm{X}$ & \\
Columbia $^{3}$ & $11 \mathrm{q} 22$ & 2.5 & & \\
Columbia $^{3}$ & $5 \mathrm{q} 33.3$ & 2.4 & & \\
\hline
\end{tabular}

${ }^{1}$ UCLA study of 270 sib-pairs (Fisher et al., 2002; Smalley et al., 2002; Ogdie et al., 2003, 2004)

${ }^{2}$ Dutch study of 164 sib-pairr (Bakker et al., 2003)

${ }^{3}$ Columbian study of 14 three-generation pedigrees (Arcos-Burgos et al., 2004)

${ }^{4}$ For review of genome scans in autism, see Muhle et al. (2004)

${ }^{5}$ For review of genome scans in dyslexia, see Demonet et al. (2004)

"Replication of same region 
ASPs to 270 ASPs and provided linkage analyses of the entire sample (Ogdie et al., 2003). Maximum LOD score (MLS) analysis identified suggestive linkage for $17 \mathrm{p} 11$ and four nominal regions with MLS values 11.0, including 5p13, 6q14, 11q25, MLS p 2.98 and 20q13. These data, taken together with the fine mapping on $16 \mathrm{p} 13$, suggested two regions as highly likely to harbor risk genes for ADHD: 16p13 and 17p11. Next, fine mapping was completed of nine positional candidate regions for ADHD in an extended population sample of 308 ASPs (Ogdie et al., 2003). The candidate chromosomal regions were selected from all three published genomewide scans for ADHD, and fine mapping was done to comprehensively validate these positional candidate regions in our sample. Multipoint maximum LOD score (MLS) analysis yielded significant evidence of linkage on 6q12 (MLS 3.30) and 17p11 (MLS 3.63), as well as suggestive evidence on 5p13 (MLS 2.55).

A second genome scan was performed on 164 Dutch affected sib pairs (ASPs) with ADHD (Bakker et al., 2003). Initially, a narrow phenotype was defined, in which all the sib pairs met the full ADHD criteria (117 ASPs). In a broad phenotype, additional sib pairs were included, in which one child had an autistic-spectrum disorder but also met the full ADHD criteria (164 ASPs). This genome scan indicated several regions of interest, two of which showed suggestive evidence for linkage. The most promising chromosome region was located at $15 \mathrm{q}$, with an MLS of 3.54 under the broad phenotype definition. This region was previously implicated in reading disability and autism. In addition, MLSs of 3.04 and 2.05 were found for chromosome regions $7 \mathrm{p}$ and $9 \mathrm{q}$ in the narrow phenotype. Except for a region on chromosome 5, no overlap was found with regions mentioned in the only other independent genome scan in ADHD reported to date.

The third genome scan was performed in 14 three-generation pedigrees with ADHD from a genetic isolate (Arcos-Burgos et al., 2004). In these families, ADHD is highly comorbid with conduct and oppositional defiant disorders, as well as with alcohol and tobacco dependence. Evidence was found of linkage to markers at chromosomes 4q13.2, 5q33.3, 8q11.23, 11q22, and $17 \mathrm{p} 11$ in individual families. Fine mapping applied to these regions resulted in significant linkage in the combined families at chromosomes 4q13, 5q33.3, 11q22 and 17p11. Additionally, suggestive linkage was found at chromosome 8q11.23. Several of these regions were novel (4q13.2, 5q33.3, and $8 \mathrm{q} 11.23)$, whereas others replicated already-published loci (11q22 and 17p11).

The lack of replication across the studies completed so far adds to the earlier conclusion that genes of moderately large effect are unlikely to exist, and for this reason, further studies are needed to increase the power of available linkage data. Another important outcome of the genome scans is that there appears to be considerable overlap in regions of the genome that are implicated in ADHD, and those that are implicated in other conditions as autism and dyslexia (Table 1).

\section{Candidate gene studies}

Numerous candidate genes have been studied for their possible association with ADHD. For more extensive review, see Faraone et al. (2005b). These candidate genes have been chosen to be relevant for current neurobiological theories of ADHD. Many groups have examined associations between 
ADHD and genes involved in dopaminergic neurotransmission, mainly because psychostimulants, among the most effective drugs used to treat ADHD, partly block the dopamine transporter (DAT1) function (Volkow et al., 2001; Buitelaar et al., 1995). Dopamine acts also as a agonist at dopaminergic receptor systems. Most studies of the dopamine transporter (DAT1-SLC6A3) gene in ADHD have examined a 10 repeat sequence in the $3^{\prime}$ untranslated region. When family-based studies of this polymorphism were pooled, the odds ratio is small but significant $(1.13,95 \%$ CI 1.03-1.24), suggesting that SLC6A3 merits further investigation but that its effect is modest. One of the best studied candidate genes is the Dopamine D4 receptor (DRD4). Researchers have predominantly focused on a tandem repeat polymorphism in exon III of DRD4 because in vitro studies have shown that one variant (the 7-repeat allele) produces a blunted response to dopamine (Asghari et al., 1995; Van Tol et al., 1992). Despite some variation across studies, when data from analyses of the exon III polymorphism are pooled, the association with ADHD remains statistically significant (case-control odds ratio $=1.45$ (95\% CI 1.27-1.65); family based OR $=1.16$ (95\% CI 1.03-1.31). Although the functional implications of mutations in DRD5 are not well understood, there is some evidence for association with long-term potentiation in corticostriatal regions and with locomotion and prepulse inhibition (Manor et al., 2004). A recent analysis that combined 14 independent samples from family-based studies (Lowe et al., 2004) identified a significant association of the $148 \mathrm{bp}$ allele with ADHD, $(\mathrm{OR}=1.2 ; 95 \%$ CI 1.1-1.4). Dopamine Beta-Hydroxylase $(\mathrm{DBH})$ is the primary enzyme responsible for conversion of dopamine to norepinephrine. When family-based studies of this gene are pooled, they jointly suggest a significant association between ADHD and the $5^{\prime}$ Taq1 polymorphism (OR $=1.33,95 \%$ CI 1.11-1.59).

The norepinephrine transporter (SLC6A2) has been examined in ADHD because drugs that block the norepinephrine transporter are efficacious in treating ADHD (Banaschewski et al., 2004). No evidence of association was found for these loci or the haplotypes comprising them in a study that examined SNPs in exon 9, intron 9 and intron 13 in 122 ADHD families and found (Barr et al., 2002). No association with intron 7 and intron 9 SNPs was seen in a study of Irish families (McEvoy et al., 2002), or with a restriction fragment length polymorphism in offspring of adults with ADHD (De Luca et al., 2004).

Serotonin transporter (SLC6A4) is perhaps the best-studied gene in psychiatric genetics, with associations reported for a broad range of diagnoses and traits (Anguelova et al., 2003a, b). When the studies of the 'long' allele of HTTLPR are combined, the pooled odds ratio for the long allele in ADHD samples is 1.31 (95\% CI 1.09-1.59). Two family-based association studies examined a silent SNP (G861C) in the gene coding for the serotonin HTR1B receptor. In predominantly Caucasian samples, both studies found over-transmission of the " $G$ " allele, though this finding only reached statistical significance in the very large study which reported pooled results from four sites (Hawi et al., 2002). The association between the over-transmission of the " $G$ " allele and ADHD reached significance as well in a study that analyzed paternal transmission (Quist et al., 2003). The pooled odds ratio for the G861C SNP is 1.44 (95\% CI 1.14-1.83). 
While these findings on candidate genes are interesting, it is important to note that these genes are of low effect size and explain only approximately $2 \%$ of the variance in symptomatology. Further, most of these studies are based on just one of possibly many functional polymorphic variations in specific genes of interest and, unfortunately, most results are inconsistent.

\section{Environmental influences}

Before turning to a discussion of the complicating factors in genetic studies, relevant environmental influences will be summarized. Several environmental risks for ADHD have been identified and these are all good candidates for moderation of genetic influences. These environmental risks can be grouped into three categories: 1) pre- and perinatal influences, such as prematurity, low birth weight, pregnancy and birth complications (Hille et al., 2001; Botting et al., 1997; Mick et al., 2002a, b), and mother's use of alcohol or tobacco during pregnancy (Milberger et al., 1996); 2) parental and family factors such as critical expressed emotion versus expressed warmth, inconsistent parenting, parental divorce, family conflict and early institutional rearing (Rutter et al., 2001; Woodward et al., 1998); and 3 ) acquired neurobiological risks such as closed head trauma and exposure to lead (Thomson et al., 1989; Max et al., 2004; Schachar et al., 2004).

Concerning obstetric adversity, a birth weight lower than $2500 \mathrm{~g}$ raises the risk to ADHD about 3-10 times (Breslau et al., 1996; Whitaker et al., 1997). A recent twin study could replicate the association between lower birth weight and increased levels of behavior problems in children as an independent main effect. Interestingly, and in addition, there was an interaction between birth weight and genetic factors in that lower birth weight was associated with decreased genetic influence (Van Os et al., 2001). Obstetric adversity may be co-dependent of the characteristics of the fetus and may mediate genetic risks, as has been shown in the case of autism (Glasson et al., 2004; Bolton et al., 1997). For example, non-affected siblings were more similar to their affected probands than to controls in their profile of birth complications (Glasson et al., 2004). Studies among clinically referred children report particularly high rates of toxemia or eclampsia, maternal illness, maternal psychological stress, bleeding, lengthy labor or delivery, and undue weight loss or gain of the pregnant mother for children with ADHD compared to control children (Milberger et al., 1997; Sprich-Buckminster et al., 1993).

Concerning family functioning, children with ADHD live in a familyenvironment characterized by marital discord, high rates of parental psychiatric disorder, and low occupation status much more often than controls (Scahill et al., 1999). Family adversity factors as marital discord, low SES, large family size, paternal criminality, maternal mental disorder, and foster placement increased the risk for ADHD and predicted for comorbid disorders, cognitive impairment, and psychosocial dysfunction (Biederman et al., 1995). It is important to appreciate that these associations between family-environment and ADHD are difficult to interprete since a number of these factors such as parental disorder may both reflect genetic transmission and exert an adverse influence through the alteration of parent-child relationships. Further, the family 
adversities may well be, in part, the consequence of having a problematic child with ADHD rather than the cause of it. Finally, these associations between factors that are defined at the level of the family as a whole, are hard to reconcile with the importance of the nonshared rather than the shared environment, as is shown by twin studies. For example, in an Australian twin study, nonshared environmental influences accounted for about $15 \%$ of the variance of ADHD symptoms (Rhee et al., 1999).

Therefore, we will review now work on disrupted parent-child relationships and hyperactivity/aggression. Careful characterization of parent-child relationships of hyperactive children derived from community studies points to the importance of abnormalities of affective tone (especially hostile expressed emotion, HEE) and impairment of parental coping skills (Taylor et al., 1991; Woodward et al., 1998). HHE was seen in $33 \%$ of mothers of hyperactive children and in $6 \%$ of healthy controls. Poor coping skills were seen in $44 \%$ of mothers of hyperactive children and $15 \%$ of healthy controls (Woodward et al., 1998). These two sets of figures give odds ratios for the two environmental factors of 7.7 and 3.8 respectively. Hostile parent-child interactions were further found to predict the longitudinal course of children with hyperactivity (Rutter et al., 1997).

Further research is needed to determine whether these are proximal risks effecting the brain directly (e.g. toxicity from alcohol), act indirectly (e.g. maternal drinking correlates with poor parenting and poor parenting is proximal risk), are genetically correlated with the genotype of the mothers (e.g. mothers with ADHD are more prone to smoke during pregnancy than mothers without ADHD) or are genetically correlated with the ADHD proband genotype (e.g. ADHD behavior evokes hostile expressed emotion in the parent).

\section{Complicating factors}

Discovering genes involved in ADHD is complicated by several factors (Table 2). The further unraveling of the genetic architecture of ADHD will depend to a large extent on how well these complicating factors are handled and even used. The first one is that the identification of genes of small main effects requires the use of very large sample sizes (Risch et al., 1996). These can only be collected by large consortia, and several of these have been formed over the past years, among which the International Multi-center ADHD GEnetics Project (IMAGE)

Table 2. Complicating factors in genetic studies in complex genetic disorders like ADHD

1. Multiple genes of small main effects

2. The relevant phenotype is unknown

3. Clinical heterogeneity

4. Genetic heterogeneity

5. Gene-environment correlation

6. Gene-environment interaction

7. Importance of endophenotypes

8. Importance of developmental factors 
Consortium (Asherson, 2004). This consortium under the leadership under Steve Faraone includes more than 10 sites in Europe and aims to collect at least 2000 ADHD families. From these, the 400 most informative concordant pairs and the 400 most informative discordant pairs will be used for initital genomewide linkage studies. Collaborative work has been further facilitated by the ADHD Molecular Genetics Network (NIH grant to Steve Faraone) which comprises investigators from around the world who currently study the genetics of ADHD and meet on a regular basis. A second forum is the EUropean NETwork of HYperactivity DISorders (Eunethydis) (leadership Joe Sergeant) which also has yearly meetings to discuss potential and actual collaboration.

A second factor is that it is unknown on which phenotype molecular-genetic studies should focus. Traditional psychiatric categories as defined in classification schemes as DSM-IV and ICD-10 have been developed for clinical purposes but have not been selected for being relevant phenotypes for genetic research. Twin studies for example indicate that ADHD, and oppositional-defiant/conduct disorder share a substantial amount of genetic factors in childhood (Silberg et al., 1996). There are several approaches to improve the definition of the relevant phenotype for genetic studies. One is based on the work of Risch (1990a, b), who proved that the statistical power of a linkage study increases with the magnitude of risk ratios computed by dividing the affection rate among each relative type (e.g., siblings, offspring) to the rate of affection in the population. These ratio's have been called "lambdas." It was shown that the power depends only on lambda and that defining disease status in a manner that increased lambda would increase the power of linkage studies. According to this logic, Faraone et al. (2000) demonstrated that lambdas were greater if the ADHD proband also has conduct disorder (4.5 and 8.6) and were even greater if the proband has persistent ADHD (17.2 and 19.5). The highest lambdas were found when the proband had both persistent ADHD and CD (25.0-25.9). Another strategy is to fully exploit the potential of twin studies to separate genetic from environmental influences. Though aggregate constructs of ADHD were shown to have heritability as high as 0.80 (see above), similar heritability estimates would not necessarily apply to the single items that are included in these constructs. Twin analyses on single items could afford further information on the decomposition of genetic and environmental influences at the item level, and result in the construction of more "pure" genetically relevant phenotypes. This strategy has been underused sofar. A third strategy is the use of newer multivariate techniques as latent class analysis on ADHD symptoms in twin designs. Such a latent class analysis was applied to data obtained from parents on the 18 DSM-IV ADHD symptoms in 4,036 female twins age 13-23 years in a population sample in Missouri (Todd et al., 2001). The latent-class analysis was most compatible with the existence of three mild and three severe classes of ADHD symptoms in the general population. Unlike DSM-IV subtypes of ADHD, latent-class ADHD subtypes appear to be independently transmitted in families. These classes may be more appropriate targets for molecular genetic studies of ADHD. In another twin dataset the inclusion of sluggish cognitive tempo items markedly changed ADHD symptom associations for boys and girls in a factor analytic framework. In contrast, latent class subtyping of ADHD shows limited impact of the inclusion of sluggish cognitive tempo items, emphasizing the very 
different assumptions about underlying continua of behavior rather than discrete classes that distinguish the two approaches (Todd et al., 2004). Sofar, latent class subtypes of ADHD have not been used in genetic linkage studies.

Linked to the previous issue of the definition of the phenotype is that of clinical heterogeneity, i.e. that different siblings in a given family may have a different clinical presentation. For example, one sibling may present with one of the ADHD subtypes, whereas another sibling may have dyslexia without ADHD and a third sibling may have autism spectrum disorder (ASD) with comorbid ADHD. The challenges but also opportunities of clinical heterogeneity have not been met addressed sufficiently, particularly in terms of the overlap between ADHD, ASD and dyslexia. Many children with ASD suffer from inattention, hyperactivity and impulsivity to an extent that clinical management of these ADHD-like symptoms is warranted (Handen et al., 2000; Quintana et al., 1995). Re-analyses of the results of population studies on deficits in attention, motor control and perception (DAMP, i.e. a combination of ADHD and perceptualmotor problems) also revealed a strong overlap between severe DAMP and ASD (Kadesjo et al., 1999; Gillberg, 1992). In a similar way, many children with Attention Deficit Hyperactivity Disorder (ADHD) have associated social deficits that are not part of the core symptoms of inattention, hyperactivity and impulsivity that define the disorder. In a study of social disability in ADHD the majority of a sample of 140 boys with ADHD had some degree of difficulty in the social domain (Greene et al., 1996); 22\% even qualified as socially disabled, as compared to none of a group of 120 normal controls. In another study, the Children's Social Behavior Questionnaire (CSBQ) was used to compare social deficits in children with ASD, children with ADHD and normal controls (Luteijn et al., 2000a, b). Children with ADHD were characterized by significant social deficits in social interaction and communication and by an increase in stereotypic and restricted behavior, in comparison with normal controls. Although these deficits were significantly more prominent in children with ASD, it appears that there may be an overlap in social deficits between subjects with ASD and ADHD (Luteijn et al., 2000a, b). This all suggests that by subtyping families with (multiple) ASD cases on ADHD characteristics and by subtyping families with (multiple) ADHD cases on ASD characteristics, one can achieve more homogeneous samples and obtain stronger signals in molecular-genetic studies and refine areas of the genome that are implicated in both disorders (Table 1). Similar considerations apply to the subtyping of dyslexia samples for ADHD and of ADHD samples for dyslexia (Loo et al., 2004).

A fourth factor is that of genetic heterogeneity, i.e. different sets of genes may be responsible for risk in different families. This locus heterogeneity may reduce power to detect linkage in traditional affected sibpair studies. On the other hand, the QTLs associated with ADHD are expected to be common genetic variants that are found across human populations (Wright et al., 1999; Risch, 2000). Thus, if population heterogeneity does exist, it is expected to lead to differing prevalence of QTLs in different groups, rather than presence or absence. In ADHD, the prevalence of the DRD4 7-repeat allele, which has been associated with ADHD, varies among populations (Chang et al., 1996). We expect this will be true of other ADHD susceptibility alleles because they 
are likely to be common alleles, which cause minor, additive deviations in neurodevelopment or neurotransmission. In spite of this, genetic heterogeneity points to the importance of genetic designs which are complementary to affected sibpair designs, such as those using extended 3-generation pedigrees.

Fifth, a full understanding of the genetics of complex behavioral disorders like ADHD will require insights into how environmental risks factors combine with genes to influence the disorder and its clinical features. Some genes might affect ADHD by influencing sensitivity to environmental risks (gene-environment interaction, $\mathrm{G} \times \mathrm{E}$ ) or modifying the probability of exposure to environmental risks (gene-environment correlation, rGE). Some other environmental risks may increase susceptibility to ADHD independent of genotype. The potential role of $\mathrm{G} \times \mathrm{E}$ effects contributing to complex behavioral disorders has recently been demonstrated by two reports from the Dunedin Multidisciplinary Health and Development Study on antisocial behavior and depression in which functional polymorphisms in candidate genes moderated the effects known of environmental stressors, with MAOA moderating the influence of parental maltreatment on antisocial behavior (Caspi et al., 2002) and the serotonin transporter gene moderating the influence of stressful life events on depression (Caspi et al., 2003). Neither of the two genes investigated showed main effects with the behavioral phenotypes in the Dunedin dataset, illustrating the important point that gene associations may be missed if environmental measures are not taken into account. To date, few molecular genetic studies of ADHD have incorporated environmental risk measures. Kahn et al. (2003) found that in pre-school children, hyperactivity-impulsivity and oppositional behavior were associated with the DAT1 10-repeat allele, but only when the child was also exposed to maternal prenatal smoking. Another study explored the possibility of an interaction between the DRD4 gene and season of birth (Seeger et al., 2004). A seasonal pattern of birth has been proposed for different subtypes of ADHD. Therefore, in a subgroup of children with ADHD and conduct disorder, and in healthy controls, children carrying the 7-repeat allele of DRD4 showed different relative risks for developing ADHD and comorbid conduct disorder, depending on the season of birth. This suggests the very likely hypothesis that ADHD, as a multifactorial disorder, may result from variations in genes which have small main effects but whose effects are conditional upon exposure to environmental risk and may be strongly amplified by these environmental risks. If risk exposure differs among participants within a sample, genes may account for little variation in the phenotype. Failure to take account of environmental risk factors in previous genetic studies may be responsible for part of the non-replication results. When exposure to environmental risks differs significantly between samples, candidate genes or regions may fail replication.

An additional strategy is to address heterogeneity at the level of endophenotypes. Endophenotypes are latent traits that are heritable, share genetic loading with the disease phenotype, and are probabilistically related to the disease phenotype as defined in DSM-IV or ICD-10 (Gottesman et al., 2003; Skuse, 2001; Leboyer et al., 1998). These latent traits, which can be measured at a physiological, neurobiological, or cognitive level, may be more closely linked to the underlying genetic factors than the behavioral phenotype and that they 


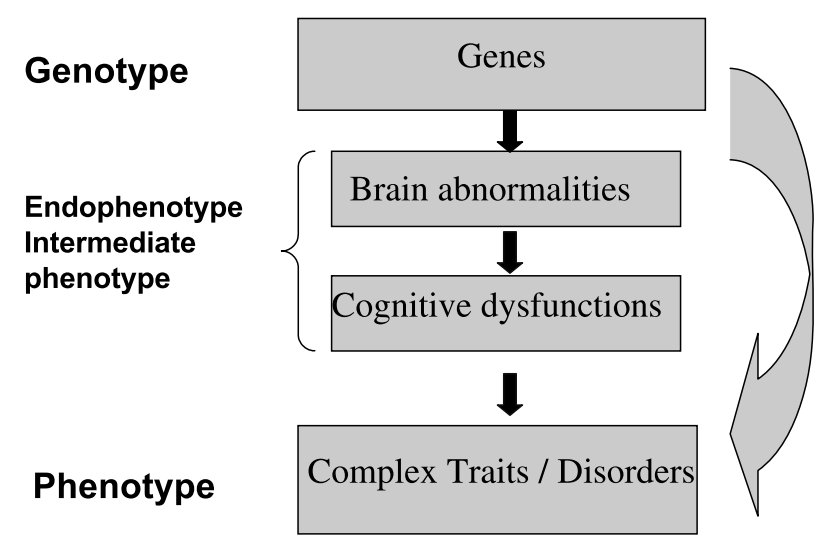

Fig. 1. Outline of the principle of the endophenotype. A smaller set of genes may be involved in the endophenotype than in the complex behavioral trait of clinical disorder

mediate gene-clinical phenotype pathways (see Fig. 1). A smaller set of genes may be involved in the endophenotypes than in the complex behavioral trait or clinical disorder. Endophenotypes may improve the power of molecular genetic studies and may also provide a means of parsing genetic heterogeneity. After many years of searching for one single simple neuropsychological deficit there is a growing realization that ADHD is probably best conceptualized as a neuropsychologically heterogenous condition with differentiable neuropsychological pathways linking specific putative causes to the clinical phenotype (SonugaBarke, 2003). These are some studies that suggest that familial ADHD may represent a form of ADHD characterized by a deficient response inhibition. In a study that included ADHD probands with a family history of ADHD, their nonaffected siblings, and normal controls matched for age and IQ, the nonaffected siblings were as impaired in measures of response inhibition as the affected probands when compared to the normal controls (Slaats-Willemse et al., 2003). Subjects with ADHD who had a family history of ADHD performed significantly worse on measures of response inhibition than subjects with ADHD without such a family history (Seidman et al., 1995). In addition, children who exhibited poor inhibition (on the stop signal task) were significantly more likely to have a first-degree relative with ADHD than were the children with ADHD who exhibited good behavioral inhibition (Crosbie et al., 2001).

The influence of increased familial risk for ADHD has also been studied on measures of brain morphology (Durston et al., 2004). Both subjects with ADHD and their unaffected siblings displayed reductions in right prefrontal gray matter and left occipital gray and white matter of up to 9.1\%. Right cerebellar volume was reduced by $4.9 \%$ in subjects with ADHD but not in their unaffected siblings. A $4.0 \%$ reduction in intracranial volume was found in subjects with ADHD, while a trend was observed in their unaffected siblings. Thus, the volumetric reductions in cortical gray and white matter in subjects with ADHD were also present in their unaffected siblings, suggesting that they are related to an increased familial risk for the disorder. In contrast, the cerebellum is unaffected in siblings, suggesting that the reduction in volume observed in subjects with ADHD may be more directly related to the pathophysiology of this disorder 
(Durston et al., 2004). A further study on the same date-set reported that the DAT1 gene, a gene expressed predominantly in the basal ganglia, preferentially influences caudate volume, whereas the DRD4 gene, a gene expressed predominantly in the prefrontal cortex, preferentially influences prefrontal gray matter volume in a sample of subjects including subjects with ADHD, their unaffected siblings, and healthy controls (Durston et al., 2005). This demonstrates that, by constraining investigations by prior knowledge of gene expression and by using endophenotypes, such as measures of brain morphology, we may begin to map out the pathways by which genes influence behaviour.

Finally, genetic studies in ADHD have disregarded the importance of developmental factors. Different genes may be operating at different ages or developmental stages. In a longitudinal twin study, the relatively high stability of ADHD symptoms over a 5-year period between age 8/9 and age 13/14 year was found. This continuity was mainly due to the same genetic effects operating at both points in time. Change in symptoms between childhood and early adolescence was to a large extent due to new genetic effects in early adolescence but also due to new nonshared environmental effects that became important during adolescence (Larsson et al., 2004). Rather similar results were obtained in another longitudinal twin study which spanned ages 3, 7, 10, and 12 year and used maternal ratings of problem behaviors (Bartels et al., 2004). Stability in externalizing behaviors was accounted for by genetic and shared environmental influences. The genetic contribution to stability for externalizing behaviors was $60 \%$ and resulted from the fact that a subset of genes expressed at an earlier age was still active at the next time point. In addition, significant age-specific influences were found for all components, indicating that genetic and environmental factors also contributed to changes in problem behavior. Genetic studies in ADHD should be enriched with a developmental perspective, and explore whether variables as age of onset and severity of disease at various points in time (rather than persistence per se) are relevant developmental endophenotypes.

\section{Concluding remarks}

Genetic research of complex disorders like ADHD is one of the most powerful tools to increase our insight into the underlying pathophysiology of the disorder. In the absence of direct neural tissue such as obtained post-mortem or by biopsy, no direct clues as to the neurochemical or cellular or molecular changes at the level of the brain are available. The identification of relevant genes opens new avenues to approach the cellular and molecular base of the disorder. Ultimately, this has the potential to individualize treatment, to facilitate prevention, and to develop new and effective treatments.

\section{References}

Alberts-Corush J, Firestone P, Goodman JT (1986) Attention and impulsivity characteristics of the biological and adoptive parents of hyperactive and normal control children. Am J Orthopsychiatry 56(3): 413-423

American Psychiatric Association (APA) (1994) Diagnostic and statistical manual of mental disorders, 4th edn (DSM-IV). APA, Washington DC 
Anguelova M, Benkelfat C, Turecki G (2003a) A systematic review of association studies investigating genes coding for serotonin receptors and the serotonin transporter. II. Suicidal behavior. Mol Psychiatry 8(7): 646-653

Anguelova M, Benkelfat C, Turecki G (2003b) A systematic review of association studies investigating genes coding for serotonin receptors and the serotonin transporter. I. Affective disorders. Mol Psychiatry 8(6): 574-591

Arcos-Burgos M, Castellanos FX, Pineda D, Lopera F, Palacio JD, Palacio LG, Rapoport JL, Berg K, Bailey-Wilson JE, Muenke M (2004) Attention-deficit/hyperactivity disorder in a population isolate: linkage to loci at 4q132 5q333 11q22 and 17p11. Am J Hum Genet 75(6): 998-1014

Asghari V, Sanyal S, Buchwaldt S, Paterson A, Jovanovic V, Van Tol HH (1995) Modulation of intracellular cyclic AMP levels by different human dopamine D4 receptor variants. J Neurochem 65(3): 1157-1165

Asherson P (2004) Attention-Deficit Hyperactivity Disorder in the post-genomic era. Eur Child Adolesc Psychiatry 13 [Suppl 1]: I50-I70

Bakker SC, van der Meulen EM, Buitelaar JK, Sandkuijl LA, Pauls DL, Monsuur AJ, Slot RvR, Minderaa RB, Gunning WB, Pearson PL, Sinke RJ (2003) A whole-genome scan in 164 dutch sib pairs with attention-deficit/hyperactivity disorder: suggestive evidence for linkage on chromosomes 7p and 15q. Am J Hum Genet 72(5): 1251-1260

Banaschewski T, Roessner V, Dittmann RW, Santosh PJ, Rothenberger A (2004) Non-stimulant medications in the treatment of ADHD. Eur Child Adolesc Psychiatry 13 [Suppl 1]: 102-116

Barkley RA, Fischer M, Edelbrock CS, Smallish L (1990) The adolescent outcome of hyperactive children diagnosed by research criteria. I. An 8-year prospective follow-up study. J Am Acad Child Adolesc Psychiatry 29(4): 546-557

Barr CL, Kroft J, Feng Y, Wigg K, Roberts W, Malone M, Ickowicz A, Schachar R, Tannock R, Kennedy JL (2002) The norepinephrine transporter gene and attention-deficit hyperactivity disorder. Am J Med Genet 114(3): 255-259

Bartels M, Van Den Oord EJ, Hudziak JJ, Rietveld MJ, van Beijsterveldt CE, Boomsma DI (2004) Genetic and environmental mechanisms underlying stability and change in problem behaviors at ages 3710 and 12. Dev Psychol 40(5): 852-867

Biederman J, Newcorn J, Sprich S (1991) Comorbidity of attention deficit hyperactivity disorder with conduct depressive anxiety and other disorders. Am J Psychiatry 148: 564-577

Biederman J, Milberger S, Faraone SV, Kiely K, Guite J, Mick E, Ablon S, Warburton R, Reed E (1995) Family-environment risk factors for attention-deficit hyperactivity disorder. A test of Rutter's indicators of adversity. Arch Gen Psychiatry 52: 464-470

Bolton PF, Murphy M, Macdonald H, Whitlock B, Pickles A, Rutter M (1997) Obstetric complications in autism: consequences or causes of the condition? J Am Acad Child Adolesc Psychiatry 36(2): 272-281

Botting N, Powls A, Cooke RWI (1997) Attention Deficit Hyperactivity Disorders and other psychiatric outcomes in very low birth weight children at 12 years. J Child Psychol Psychiatry 38: 931-941

Breslau N, Brown GG, DelDotto JE, Kumar S, Ezhuthachan S, Andreski P, Hufnagle KG (1996) Psychiatric sequelae of low birth weight at 6 years of age. J Abnorm Child Psychol 24(3): $385-400$

Buitelaar JK (2002) Epidemiological aspects: what have we learned over the last decade? In: Sandberg S (ed) Hyperactivity and attention disorders of childhood, $2^{\text {nd }}$ edn. Cambridge University Press, Cambridge, pp 30-63

Buitelaar JK, Rothenberger A (2004) Foreword - ADHD in the scientific and political context. Eur Child Adolesc Psychiatry 13 [Suppl 1]: 1-6

Buitelaar JK, Van der Gaag RJ, Swaab-Barneveld H, Kuiper M, Van Engeland H (1995) Prediction of clinical response to methylphenidate in children with attention-deficit hyperactivity disorder (abstract). Proc 10th ESCAP Congress 10: 92-93

Cantwell DP (1975) Genetics of hyperactivity. J Child Psychol Psychiatr Allied Disciplines 16(3): 261-264

Caspi A, McClay J, Moffitt TE, Mill J, Martin J, Craig IW, Taylor A, Poulton R (2002) Role of genotype in the cycle of violence in maltreated children. Science 297: 851-854 
Caspi A, Sugden K, Moffitt TE, Taylor A, Craig IW, Harrington H, McClay J, Mill J, Martin J, Braithwaite A, Poulton R (2003) Influence of life stress on depression: moderation by a polymorphism in the 5-HTT gene. Science 301(5631): 386-389

Chang FM, Kidd JR, Livak KJ, Pakstis AJ, Kidd KK (1996) The world-wide distribution of allele frequencies at the human dopamine D4 receptor locus. Hum Genet 98(1): 91-101

Crosbie J, Schachar R (2001) Deficient inhibition as a marker for familial ADHD. Am J Psychiatry 158(11): 1884-1890

De Luca V, Muglia P, Vincent JB, Lanktree M, Jain U, Kennedy JL (2004) Adrenergic alpha 2C receptor genomic organization: association study in adult ADHD. Am J Med Genet B Neuropsychiatr Genet 127(1): 65-67

Demonet JF, Taylor MJ, Chaix Y (2004) Developmental dyslexia. Lancet 363(9419): 1451-1460

Durston S, Hulshoff Pol HE, Schnack HG, Buitelaar JK, Steenhuis MP, Minderaa RB, Kahn RS, Van Engeland H (2004) Magnetic resonance imaging of boys with attention-deficit/hyperhyperactivity disorder and their unaffected siblings. J Am Acad Child Adolesc Psychiatry 43(3): $332-340$

Durston S, Fossella JA, Casey BJ, Hulshoff Pol HE, Galvan A, Schnack HG, Steenhuis MP, Minderaa RB, Buitelaar JK, Kahn RS, Van Engeland H (2005) Differential effects of DRD4 and DAT1 genotype on fronto-striatal gray matter volumes in a sample of subjects with attention deficit hyperactivity disorder their unaffected siblings and controls. Mol Psychiatry 10(7): 678-685

Faraone SV (2005a) The scientific foundation for understanding attention-deficit/hyperactivity disorder as a valid psychiatric disorder. Eur Child Adolesc Psychiatr 14(1): 1-10

Faraone SV, Perlis RH, Doyle AE, Smoller JW, Goralnick JJ, Holmgren MA, Sklar P (2005b) Molecular genetics of attention deficit hyperactivity disorder. Biol Psychiatry 57(11): 1313-1323

Faraone SV, Biederman J (1994) Genetics of attention-deficit hyperactivity disorder. Child Adolesc Psychiatr Clin N Am 3: 285-302

Faraone SV, Doyle AE (2001) The nature and heritability of attention-deficit/hyperactivity disorder. Child Adolesc Psychiatr Clin N Am 10(2): 299-316 viii-ix

Faraone SV, Biederman J, Monuteaux MC (2000) Toward guidelines for pedigree selection in genetic studies of Attention Deficit Hyperactivity Disorder. Genet Epidemiol 18: 1-16

Fisher SE, Francks C, McCracken JT, McGough JJ, Marlow AJ, Macphie IL, Newbury DF, Crawford LR, Palmer CG, Woodward JA, Del'Homme M, Cantwell DP, Nelson SF, Monaco AP, Smalley SL (2002) A genomewide scan for loci involved in attention-deficit/ hyperactivity disorder. Am J Hum Genet 70(5): 1183-1196

Fossati A, Novella L, Donati D, Donini M, Maffei C (2002) History of childhood attention deficit/hyperactivity disorder symptoms and borderline personality disorder: a controlled study. Compr Psychiatry 43(5): 369-377

Gillberg CL (1992) Autism and autistic-like conditions - subclasses among disorders of empathy. J Child Psychol Psychiat 33: 813-842

Glasson EJ, Bower C, Petterson B, de Klerk N, Chaney G, Hallmayer JF (2004) Perinatal factors and the development of autism: a population study. Arch Gen Psychiatry 61(6): 618-627

Gottesman II, Gould TD (2003) The endophenotype concept in psychiatry: etymology and strategic intentions. Am J Psychiatry 160(4): 636-645

Greene RW, Biederman J, Faraone SV, Ouellette CA, Penn C, Griffin SM (1996) Toward a new psychometric definition of social disability in children with attention-deficit hyperactivity disorder. J Am Acad Child Adolesc Psychiatry 35(5): 571-578

Handen BL, Johnson CR, Lubetsky MJ (2000) Efficacy of methylphenidate among children with autism and symptoms of attention-deficit hyperactivity disorder. J Autism Dev Disord 30: $245-255$

Hawi Z, Dring M, Kirley A, Foley D, Kent L, Craddock N, Asherson P, Curran S, Gould A, Richards S, Lawson D, Pay H, Turic D, Langley K, Owen M, O'Donovan M, Thapar A, Fitzgerald M, Gill M (2002) Serotonergic system and attention deficit hyperactivity disorder (ADHD): a potential susceptibility locus at the 5-HT(1B) receptor gene in 273 nuclear families from a multi-centre sample. Mol Psychiatry 7(7): 718-725

Hille ET, den Ouden AL, Saigal S, Wolke D, Lambert M, Whitaker A, Pinto-Martin JA, Hoult L, Meyer R, Feldman JF, Verloove-Vanhorick SP, Paneth N (2001) Behavioural problems in children who weigh $1000 \mathrm{~g}$ or less at birth in four countries. Lancet 357(9269): 1641-1643 
Kadesjo B, Gillberg C, Hagberg B (1999) Brief report: autism and Asperger syndrome in sevenyear-old children: a total population study. J Autism Dev Disord 29(4): 327-331

Kahn RS, Khoury J, Nichols WC, Lanphear BP (2003) Role of dopamine transporter genotype and maternal prenatal smoking in childhood hyperactive-impulsive inattentive and oppositional behaviors. J Pediatr 143(1): 104-110

Larsson JO, Larsson H, Lichtenstein P (2004) Genetic and environmental contributions to stability and change of ADHD symptoms between 8 and 13 years of age: a longitudinal twin study. J Am Acad Child Adolesc Psychiatry 43(10): 1267-1275

Leboyer M, Bellivier F, Nosten-Bertrand M, Jouvent R, Pauls D, Mallet J (1998) Psychiatric genetics: search for phenotypes. Trends Neurosci 21(3): 102-105

Levy F, Hay DA, McStephen M, Wood C, Waldman I (1997) Attention-deficit hyperactivity disorder: a category or a continuum? Genetic analysis of a large-scale twin study. J Am Acad Child Adolesc Psychiatry 36(6): 737-744

Loo SK, Fisher SE, Francks C, Ogdie MN, Macphie IL, Yang M, McCracken JT, McGough JJ, Nelson SF, Monaco AP, Smalley SL (2004) Genome-wide scan of reading ability in affected sibling pairs with attention-deficit/hyperactivity disorder: unique and shared genetic effects. Mol Psychiatry 9(5): 485-493

Lowe N, Kirley A, Hawi Z, Sham P, Wickham H, Kratochvil CJ, Smith SD, Lee SY, Levy F, Kent L, Middle F, Rohde LA, Roman T, Tahir E, Yazgan Y, Asherson P, Mill J, Thapar A, Payton A, Todd RD, Stephens T, Ebstein RP, Manor I, Barr CL, Wigg KG, Sinke RJ, Buitelaar JK, Smalley SL, Nelson SF, Biederman J, Faraone SV, Gill M (2004) Joint analysis of the DRD5 marker concludes association with Attention-Deficit/Hyperactivity Disorder confined to the predominantly inattentive and combined subtypes. Am J Hum Genet 74(2): 348-356

Luteijn E, Luteijn F, Jackson S, Volkmar F, Minderaa R (2000a) The children's Social Behavior Questionnaire for milder variants of PDD problems: evaluation of the psychometric characteristics. J Autism Dev Disord 30(4): 317-330

Luteijn EF, Serra M, Jackson S, Steenhuis MP, Althaus M, Volkmar F, Minderaa R (2000b) How unspecified are disorders of children with a pervasive developmental disorder not otherwise specified? A study of social problems in children with PDD-NOS and ADHD. Eur Child Adolesc Psychiatry 9(3): 168-179

Mannuzza S, Gittelman Klein R, Horowitz Konig P, Giampino TL (1989) Hyperactive boys almost grown up. IV. Criminality and its relationship to psychiatric status. Arch Gen Psychiatry 46: 1073-1079

Manor I, Corbex M, Eisenberg J, Gritsenkso I, Bachner-Melman R, Tyano S, Ebstein RP (2004) Association of the dopamine D5 receptor with attention deficit hyperactivity disorder (ADHD) and scores on a continuous performance test (TOVA). Am J Med Genet B Neuropsychiatr Genet 127(1): 73-77

Max JE, Lansing AE, Koele SL, Castillo CS, Bokura H, Schachar R, Collings N, Williams KE (2004) Attention deficit hyperactivity disorder in children and adolescents following traumatic brain injury. Dev Neuropsychol 25(1-2): 159-177

McEvoy B, Hawi Z, Fitzgerald M, Gill M (2002) No evidence of linkage or association between the norepinephrine transporter (NET) gene polymorphisms and ADHD in the Irish population. Am J Med Genet 114(6): 665-666

Mick E, Biederman J, Faraone SV, Sayer J, Kleinman S (2002a) Case-control study of attentiondeficit hyperactivity disorder and maternal smoking alcohol use and drug use during pregnancy. J Am Acad Child Adolesc Psychiatry 41(4): 378-385

Mick E, Biederman J, Prince J, Fischer MJ, Faraone SV (2002b) Impact of low birth weight on attention-deficit hyperactivity disorder. J Dev Behav Pediatr 23(1): 16-22

Milberger S, Biederman J, Faraone SV, Chen L, Jones J (1996) Is maternal smoking during pregnancy a risk factor for attention deficit hyperactivity disorder in children? [see comments] Am J Psychiatry 153(9): 1138-1142

Milberger S, Biederman J, Faraone SV, Guite J, Tsuang MT (1997) Pregnancy delivery and infancy complications and attention deficit hyperactivity disorder: issues of gene-environment interaction. Biol Psychiatry 41(1): 65-75

Morrison JR, Stewart MA (1973) The psychiatric status of the legal families of adopted hyperactive children. Arch Gen Psychiatry 28(6): 888-891 
Muhle R, Trentacoste SV, Rapin I (2004) The genetics of autism. Pediatrics 113(5): e472-486

Ogdie MN, Macphie IL, Minassian SL, Yang M, Fisher SE, Francks C, Cantor RM, McCracken JT, McGough JJ, Nelson SF, Monaco AP, Smalley SL (2003) A genomewide scan for attention-deficit/hyperactivity disorder in an extended sample: suggestive linkage on $17 \mathrm{p} 11$. Am J Hum Genet 72(5): 1268-1279

Quintana H, Birmaher B, Stedge D, Lennon S, Freed J, Bridge J, Greenhill L (1995) Use of methylphenidate in the treatment of children with autistic disorder. J Autism Dev Disord 25(3): 283-294

Quist JF, Barr CL, Schachar R, Roberts W, Malone M, Tannock R, Basile VS, Beitchman J, Kennedy JL (2003) The serotonin 5-HT1B receptor gene and attention deficit hyperactivity disorder. Mol Psychiatry 8(1): 98-102

Rhee SH, Waldman ID, Hay DA, Levy F (1999) Sex differences in genetic and environmental influences on DSM-III-R attention-deficit/hyperactivity disorder. J Abnorm Psychol 108(1): 24-41

Risch N (1990a) Linkage strategies for genetically complex traits. II. The power of affected relative pairs. Am J Hum Genet 46(2): 229-241

Risch N (1990b) Linkage strategies for genetically complex traits. I. Multilocus models. Am J Hum Genet 46(2): 222-228

Risch NJ (2000) Searching for genetic determinants in the new millennium. Nature 405(6788): $847-856$

Risch NJ, Zhang H (1996) Mapping quantitative trait loci with extreme discordant sib pairs: sampling considerations. Am J Hum Genet 58(4): 836-843

Robins E, Guze SB (1970) Establishment of diagnostic validity in psychiatric illness: its application to schizophrenia. Am J Psychiatry 126(7): 983-987

Robinson WP, Wagstaff J, Bernasconi F, Baccichetti C, Artifoni L, Franzoni E, Suslak L, Shih LY, Aviv H, Schinzel AA (1993) Uniparental disomy explains the occurrence of the Angelman or Prader-Willi syndrome in patients with an additional small inv dup(15) chromosome. J Med Genet 30(9): 756-760

Rutter M, Maughan B, Meyer J, Pickles A, Silberg J, Simonoff E, Taylor E (1997) Heterogeneity of antisocial behavior: causes continuities and consequences. Nebr Symp Motiv 44: 45-118

Rutter ML, Kreppner JM, O'Connor TG (2001) Specificity and heterogeneity in children's responses to profound institutional privation. Br J Psychiatry 179: 97-103

Scahill L, Schwab-Stone ME, Merikangas KR, Leckman JF, Zhang H, Kasl S (1999) Psychosocial and clinical correlates of ADHD in a community sample of school-age children. J Am Acad Child Adolesc Psychiatry 38(8): 976-984

Schachar R, Levin HS, Max JE, Purvis K, Chen S (2004) Attention deficit hyperactivity disorder symptoms and response inhibition after closed head injury in children: do preinjury behavior and injury severity predict outcome? Dev Neuropsychol 25(1-2): 179-198

Seeger G, Schloss P, Schmidt MH, Ruter-Jungfleisch A, Henn FA (2004) Gene-environment interaction in hyperkinetic conduct disorder $(\mathrm{HD}+\mathrm{CD})$ as indicated by season of birth variations in dopamine receptor (DRD4) gene polymorphism. Neurosci Lett 366(3): $282-286$

Seidman LJ, Biederman J, Faraone SV, Milberger S, Norman D, Seiverd K, Benedict K, Guite J, Mick E, Kiely K (1995) Effects of family history and comorbidity on the neuropsychological performance of children with ADHD: preliminary findings. J Am Acad Child Adolesc Psychiatry 34(8): 1015-1024

Semrud-Clikeman M, Biederman J, Sprich-Buckminster S, Lehman BK, Faraone SV, Norman D (1992) Comorbidity between ADDH and learning disability: a review and report in a clinically referred sample. J Am Acad Child Adolesc Psychiatry 31(3): 439-448

Sherman DK, Iacono WG, McGue MK (1997) Attention-deficit hyperactivity disorder dimensions: a twin study of inattention and impulsivity-hyperactivity. J Am Acad Child Adolesc Psychiatry 36(6): 745-753

Silberg J, Rutter M, Meyer J, Maes H, Hewitt J, Simonoff E, Pickles A, Loeber R, Eaves L (1996) Genetic and environmental influences on the covariation between hyperactivity and conduct disturbance in juvenile twins. J Child Psychol Psychiatry 37(7): 803-816 
Skuse DH (2001) Endophenotypes and child psychiatry. Br J Psychiatry 178: 395-396

Slaats-Willemse DIE, Swaab-Barneveld H, De Sonneville LMJ, van der Meulen EM, Buitelaar JK (2003) Deficient response inhibition as a cognitive endophenotype of ADHD. J Am Acad Child Adolesc Psychiatry 42: 1242-1248

Smalley SL, Kustanovich V, Minassian SL, Stone JL, Ogdie MN, McGough JJ, McCracken JT, Macphie IL, Francks C, Fisher SE, Cantor RM, Monaco AP, Nelson SF (2002) Genetic linkage of attention-deficit/hyperactivity disorder on chromosome 16p13 in a region implicated in autism. Am J Hum Genet 71(4): 959-963

Sonuga-Barke EJ (2003) The dual pathway model of AD/HD: an elaboration of neurodevelopmental characteristics. Neurosci Biobehav Rev 27(7): 593-604

Sprich-Buckminster S, Biederman J, Milberger S, Faraone SV, Lehman BK (1993) Are perinatal complications relevant to the manifestation of ADD? Issues of comorbidity and familiality. J Am Acad Child Adolesc Psychiatry 32(5): 1032-1037

Taylor E, Sandberg S, Thorley G, Giles S (1991) The epidemiology of hyperactivity. Oxford University Press, Oxford

Thapar A, Holmes J, Poulton K, Harrington R (1999) Genetic basis of attention deficit and hyperactivity. Br J Psychiatry 174: 105-111

Thomson GOB, Raab GM, Hepburn WS, Hunter R, Fulton M, Laxen DPH (1989) Lood-lead levels and children's behavior: results from the Edinburgh lead study. J Child Psychol Psychiat 30: 515-528

Todd RD, Rasmussen ER, Neuman RJ, Reich W, Hudziak JJ, Bucholz KK, Madden PA, Heath A (2001) Familiality and heritability of subtypes of attention deficit hyperactivity disorder in a population sample of adolescent female twins. Am J Psychiatry 158(11): 1891-1898

Todd RD, Rasmussen ER, Wood C, Levy F, Hay DA (2004) Should sluggish cognitive tempo symptoms be included in the diagnosis of attention-deficit/hyperactivity disorder? J Am Acad Child Adolesc Psychiatry 43(5): 588-597

Van Os J, Wichers M, Danckaerts M, Van Gestel S, Derom C, Vlietinck R (2001) A prospective twin study of birth weight discordance and child problem behavior. Biol Psychiatry 50(8): 593-599

Van Tol HH, Wu CM, Guan HC, Ohara K, Bunzow JR, Civelli O, Kennedy J, Seeman P, Niznik HB, Jovanovic V (1992) Multiple dopamine D4 receptor variants in the human population. Nature 358: 149-152

Volkow ND, Wang G, Fowler JS, Logan J, Gerasimov M, Maynard L, Ding Y, Gatley SJ, Gifford A, Franceschi D (2001) Therapeutic doses of oral methylphenidate significantly increase extracellular dopamine in the human brain. J Neurosci 21(2): RC121

Weiss G, Hechtman L (1993) Hyperactive childen grown up ADHD in children adolescents and adults, 2nd ed. Guilford Press, New York

Whitaker AH, Van Rossum R, Feldman JF, Schonfeld IS, Pinto-Martin JA, Torre C, Shaffer D, Paneth N (1997) Psychiatric outcomes in low-birth-weight children at age 6 years: relation to neonatal cranial ultrassound abnormalities. Arch Gen Psychiatry 54: 847-856

Wilens TE (2004) Attention-deficit/hyperactivity disorder and the substance use disorders: the nature of the relationship subtypes at risk and treatment issues. Psychiatr Clin N Am 27(2): 283-301

Woodward L, Taylor E, Dowdney L (1998) The parenting and family functioning of children with hyperactivity. J Child Psychol Psychiatr Allied Disciplines 39(2): 161-169

Wright AF, Carothers AD, Pirastu M (1999) Population choice in mapping genes for complex diseases. Nat Genet 23(4): 397-404

Author's address: J. K. Buitelaar, Department of Psychiatry (333), Radboud University Nijmegen Medical Center, P.O. Box 9101, 6500 HB Nijmegen, The Netherlands, e-mail: J.Buitelaar@psy.umcn.nl 